\title{
Integration of Cold Ironing and Renewable Sources in the Barcelona Smart Port
}

\author{
Alejandro Rolán ${ }^{\circledR}$, Paola Manteca, Rahime Oktar, and Pierluigi Siano ${ }^{\circledR}$, Senior Member, IEEE
}

\begin{abstract}
Cold ironing, which is the procedure of supplying shoreside electrical power to a ship at berth when its engines are turned OFF, arises as the eco-friendly way to deliver power to ships while they are berthed in ports, thus avoiding the use of diesel engines onboard, which provokes the emission of large amounts of greenhouse gases into the atmosphere. The aim of this study is twofold. First, a survey of research developments on cold ironing is carried out in order to show the state-of-the-art on the problem of greenhouse gases emitted by ships while docked and how to tackle it. Current regulations and examples of current ports that make use of technologies for cold ironing purposes are also shown. Second, the study proposes the use of a cold ironing system in the port of Barcelona, where the power generation is entirely given by renewable energy systems (wind turbines and photovoltaic panels). The idea is to contribute to the wide spread of cold ironing within smart port microgrids to achieve the goal of zero emissions from berthed ships.
\end{abstract}

Index Terms-Cold ironing, microgrid, renewable energies, smart port.

\section{AMP \\ CMS \\ $\mathrm{CO}_{2}$ \\ DER \\ DFIG \\ EEDI \\ EPA \\ FACT \\ GHG \\ $\mathrm{HVdc}$ \\ HVSC}

ICCT International Council on Clean Transportation.

IMO International Maritime Organization.

LES Local energy storage.

LNG Liquefied natural gas.

LPG Liquefied petroleum gas.

MARPOL Marine Pollution.

MEPC Marine Environment Protection Committee.

MMC Modular multilevel converter.

MPPT Maximum power point tracking.

$\mathrm{NO}_{\mathrm{x}} \quad$ Nitrogen oxides.

PLL Phase-locked loop.

PM 2.5 Particulate matter whose diameter is $<2.5 \mu \mathrm{m}$.

PSS

PV

RES

RoRo

S2S

SECA

$\mathrm{SO}_{2}$

WT

Power system stabilizer.

Photovoltaic.

Renewable energy source.

Roll-on and roll-off.

Shore-to-ship.

Sulphur emissions control area.

Sulphur dioxide.

Wind turbine.

\section{INTRODUCTION}

C ARBON combustion sends to the atmosphere the socalled GHGs, which contribute to climate change. Certainly, the increase in both global temperature and see level is one of the most critical issues that humanity needs to face up with. Among all the GHGs, the most common ones are $\mathrm{NO}_{\mathrm{x}}$, $\mathrm{CO}_{2}, \mathrm{SO}_{2}$, and PM 2.5 [1], [2]. It should be noted that GHGs emissions do not only cause global warming, but also a threat to human health. Indeed, the airborne particles that get into lungs are small enough to pass through tissues and enter the blood and thus provoking health problems, such as asthma or even premature death due to carcinogenic particles [3].

Between 2007 and 2012, one billion tons of GHGs were emitted by ships, which turned out to be around $3 \%$ of overall GHGs around the world [4]. The following GHGs are emitted (per year) to the atmosphere from international shipping [5]: 1.7 million tons of $\mathrm{SO}_{2}, 2.8$ million tons of $\mathrm{NO}_{\mathrm{x}}$, and 195000 tons of PM 2.5. In the case of ocean going vessels, they usually emit to the atmosphere between 1.2 and 1.6 metric tons of PM with diameter less than $10 \mu \mathrm{m}$, between 4.7 and 6.5 tons of $\mathrm{SO}_{2}$, and between 5 and 6.9 tons of $\mathrm{NO}_{\mathrm{x}}$ [6], [7]. Furthermore, studies reveal that PM 2.5 emitted by ships have been categorized to cause a major effect of cardiopulmonary and lung cancer mortalities in populations exposed in coastal areas [3], [8]. 


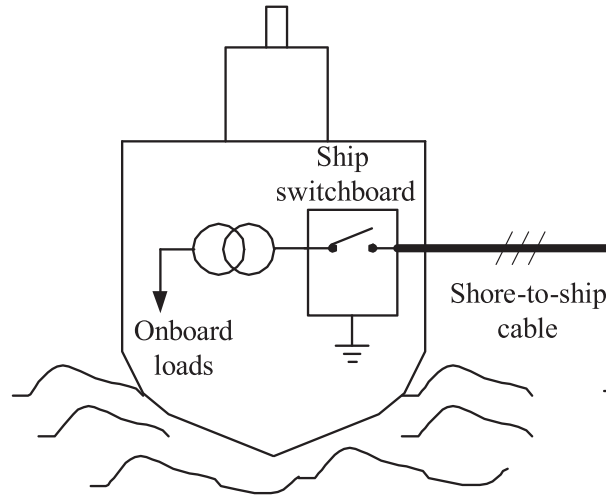

Ship infrastructure for cold ironing
Shore switchboard
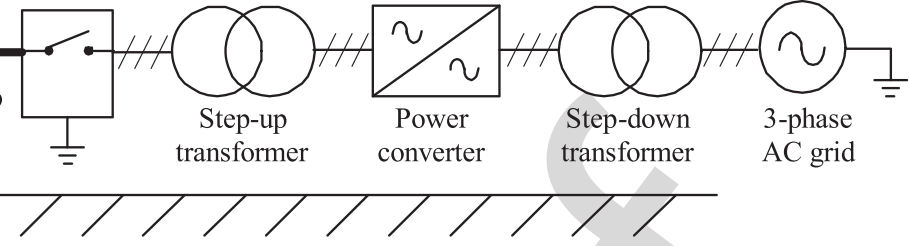

Port infrastructure for cold ironing

Fig. 1. Infrastructure requirements of a cold ironing system (adapted from [16]).

\section{A. Background}

115 Reducing emissions in ports is a matter of special importance 116 due to their proximity to human settlements. Ships require power 117 even while they are docked in ports to provide electricity for their lighting, cooling, heating, and other ancillary services. 118 The electricity is generated by electrical machines connected to 119 diesel motors, which are placed onboard [14]. So, diesel engines 120 are the primary source of energy for ships. An alternative is to 121 use either LNG or LPG to run diesel engines [15], but it has the 122 drawback of noise pollution. An eco-friendly way to generate 123 this electricity for berthed ships is to do it on-shore, so that the 124 ships' diesel engines are turned OFF. This process is named cold 125 ironing (i.e., iron pipes in the smokestack become "cold" as they 126 are not working) [16], [17], which is also known as AMP [18], 127 HVSC [19] or S2S power [20]. To that purpose, RES, such as 128 wind energy or wave energy, can be used to construct a smart 129 port to achieve the aim of zero emissions while berthing [21]. 130 Naturally, the use of cold ironing eliminates the emission of 131 GHGs due to the use of carbon combustion in diesel engines 132 and shifts the burden to power generation facilities in local grids. 133 The different applications of cold ironing systems can be found 134 in [22] and [23].

\section{B. Ship Requirements While Berthing}

By using cold ironing systems, emission-free solution would 137 be fulfilled for berthed ships while plugging to the shore-side 138 electrical grid. The essential equipment to provide electricity 139 to berthed ships consists of a step-down transformer, a power 140 converter, a step-up transformer, a shore-to-ship cable, a shore- 141 side switchboard, and a ship-side switchboard, as depicted in 142 Fig. 1 (adapted from [16]).

First, a step-down transformer is needed to decrease the high- 144 voltage level given by a three-phase electrical grid into a mid- 145 voltage level (from 10 to $35 \mathrm{kV}$ [24]). Second, a power converter 146 is used to obtain the required frequency for a ship. It should 147 be noted that different countries might work at different fre- 148 quencies. For example, the grid frequency in Europe is $50 \mathrm{~Hz}, 149$ whereas in North America, it is $60 \mathrm{~Hz}$. It implies that if a ship 150 is built in one continent, the cold ironing system in another con- 151 tinent must use a proper power converter which is able to feed 152 voltage to either 50 or $60 \mathrm{~Hz}$ [24]. Third, a step-up transformer 153 is needed to adjust the shore-side voltage to the ship voltage 154 requirements $(6.6$ or $11 \mathrm{kV})$ [24]. Finally, a cable must connect 155 both shore-side transformers with the ship electrical infrastruc- 156 ture. This cable is connected by means of two switchboards 157 
TABLE I

VOLTAGE AND POWER REQUIREMENTS FOR BERTHED SHIPS (FROM [24])

\begin{tabular}{lll}
\hline \hline Ship type & $\begin{array}{c}\text { Voltage requirements } \\
\text { (phase-to-phase value) }\end{array}$ & Power requirements \\
\hline Cruise & $6.6 \mathrm{kV}$ or $11 \mathrm{kV}$ & $16-20 \mathrm{MVA}$ \\
Container & $6.6 \mathrm{kV}$ & $7.5 \mathrm{MVA}$ \\
LNG carrier & $6.6 \mathrm{kV}$ or $11 \mathrm{kV}$ & $10.7 \mathrm{MVA}$ \\
RoRo & $11 \mathrm{kV}$ & $6.5 \mathrm{MVA}$ \\
Tanker & $6.6 \mathrm{kV}$ & $7.2 \mathrm{MVA}$ \\
\hline \hline
\end{tabular}

at the two ends of the shore-to-ship cable. It should be noted that this cable is very heavy, as it needs to provide mid-voltage level, so a CMS, such as a crane, is needed to handle it [25]. Additionally, the traditional ships need to be modified to allow connection to the shore power system, and some ships may also need a high-voltage certified electrician onboard [26].

A proper cold ironing system must be designed to satisfy the electrical demand (both voltage and power requirements) of different ships at berth. Ships and their electrical demands can be classified into the following:

1) cruise ships, which require either $6.6 \mathrm{kV}$ or $11 \mathrm{kV}$ and 16-20 MVA;

2) container ships, whose requirements are $6.6 \mathrm{kV}$ and 7.5 MVA;

3) LNG carriers, requiring $6.6 \mathrm{kV}$ or $11 \mathrm{kV}$ and $10.7 \mathrm{MVA}$;

4) RoRo ships, whose needs are $11 \mathrm{kV}$ and $6.5 \mathrm{MVA}$; and

5) tankers, which require $6.6 \mathrm{kV}$ and 7.2 MVA.

Table I summarizes these requirements (adapted from [24]).

\section{Regulations on Cold Ironing}

Until recently, there has not existed a universal regulation on cold ironing. There have been different regulations in different countries regarding the reduction of ships' GHGs emissions, which are compared in [27]. In 2012, the first international standard on cold ironing was launched: the IEC/ISO/IEEE 80005-1 provided the utility connection requirements in ports for HVSC systems [28], and in 2016, the second part of this international standard established data communication for monitoring and control [29]. According to this international standard, the general issues to look at when implementing a cold ironing system can be categorized as power quality, socket/connector configuration, conversion equipment, galvanic isolation, neutral earthing resistor and equipment bonding, short-circuit protection, circuit breakers, safety interlocks, and interface equipment.

\section{Microgrids and Smart Ports}

Nowadays, there has been a noticeable increase in energy consumption worldwide, and people's awareness on environmental issues is gaining importance and energy market liberalization is progressing steadily. Furthermore, traditional power systems based on centralized power plants are being substituted by distributed generation based on RES. The aforementioned reasons make it possible for governments to foster policies in order to promote the use of RESs and distributed power systems. To that 199 purpose, the concept of microgrid arises as the way to create 200 an independent grid with distributed generation which has the 201 ability to either operate connected to the main grid or in the 202 islanding mode [30], [31].

In port areas that have enough amount of renewable energy 204 resources, DERs can be used to implement a microgrid within 205 them [32]. When managed correctly, the port becomes a "smart 206 port" or "wise port" [33], in resemblance with the so-called 207 "smart grids", where there exists not only a flow of energy but 208 also a flow of data, which are managed properly to determine 209 an efficient and intelligent distribution of energy through all the 210 power system [34], [35]. 211

DERs include both LES systems and renewable-based dis- 212 tributed generation, such as marine energy generators (e.g., wave 213 or marine current), PV farms or wind farms. When implement- 214 ing a microgrid within a port infrastructure, both costs and reg- 215 ulations, as well as sustainability issues, need to be considered. 216 Moreover, it should be noted that the port operation requires 217 high amounts of electricity [36], [37], which can be compared 218 with the electrical loads of a small city. Consequently, micro- 219 grids provide an interesting opportunity to allow ports meet their 220 energy requirements by making use of RES.

\section{E. Current Ports With Cold Ironing Systems}

Cold ironing systems are being used nowadays in some ports 223 around the world. An example of a smart port using this tech- 224 nology is the USA Port of Long Beach in California [38]. The 225 California Air Resources Board has estimated that GHGs emis- 226 sions could be reduced by $70 \%$ (around 18 tons per day) if every 227 ship berthed three or more times per year in California's ports 228 made use of a cold ironing system [39]. Furthermore, since 2010229 the EPA from the State of California has been promoting the use 230 of standards on cold ironing in order to meet the emissions re- 231 ductions limits [40]. Then, due to these and other environmental 232 laws, more ports in both California and Alaska are nowadays 233 using HVSC systems for cruise and large container ships. 234 California's ports have planned $6.6 \mathrm{kV}$ supply voltage with 235 power delivery up to $7.5 \mathrm{MVA}$ per berth. Coordinated develop- 236 ment of analytical techniques, port infrastructure, and onboard 237 electrical generation will ease the execution of cold ironing 238 systems for ships [41].

More examples of ports using cold ironing systems can be 240 located in Europe, such as

1) the port of Gothenburg (Sweden [42]);

2) the port of Oslo (Norway) [43];

3) the port of Rotterdam (The Netherlands) [44];

4) the port of Hamburg (Germany) [45]; or

5) the port of Vigo (Spain) [46].

In Asia and Oceania, the port of Tanjung Perak (Indonesia) 247 [47] can be taken as an example. In all the aforementioned 248 cases and the future smart ports, the integration of microgrid 249 technology in ports and the government's policies to increase 250 people's awareness on climate change is an essential require- 251 ment to achieve the goal of zero-emissions port. 


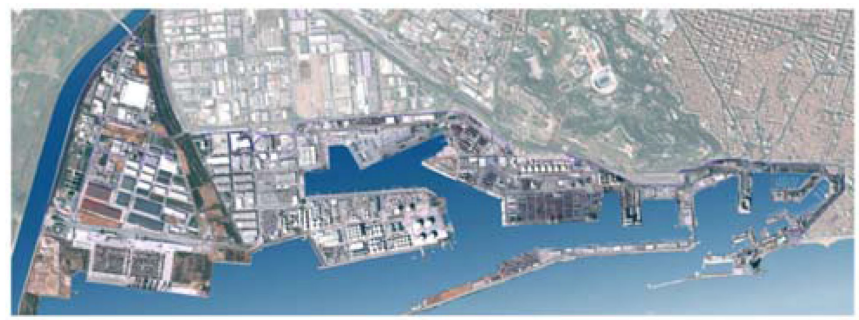

(a)

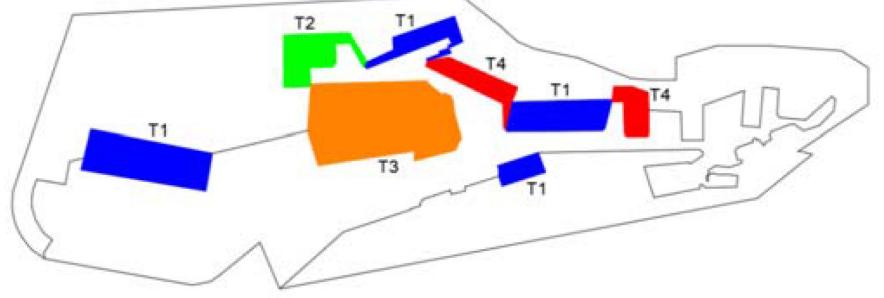

(b)

Fig. 2. Layout of the port of Barcelona. (a) Orthophotography (obtained from [48]). (b) Port terminals (authors' composition). T1 = terminal for containers and multipurpose ships; T2 = terminal for car carriers; T3 = terminal for LNG carriers and tankers; and T4 = terminal for bulk carriers

\section{Proposed Cold Ironing System For the Port OF BARCELONA}

\section{A. Port Layout and Terminals}

The port of Barcelona has terminals for passengers, a leisure port called "Port Vell," and terminals for commercial activity. This paper focuses its attention on the latter. The commercial port is divided into four terminals according to the ship type, as depicted in Fig. 2 (adapted from [48]). The port terminals are subdivided as follows: T1 has two sections, one used by containers and another one used by multipurpose ships; $\mathrm{T} 2 \mathrm{has}$ one section, which is used by car carriers: T3 is used by liquid cargo vessels and is divided into two sections, one for LNG carriers and another one for tankers; finally, T4 has two sections that are used by bulk carriers.

\section{B. Electrical Demand From Berthed Ships}

Table II (adapted from [49], [50] and from confidential data given by the Authority of the Port of Barcelona) shows the hourly electrical demand from berthed ships at the port of Barcelona, considering all the per-hour arrivals and departures. The demanded power by berthed ships at a given time $i, P_{i}$, is calculated as follows:

$$
P_{i}=P_{i-1}+P_{\text {arr }}-P_{\text {dep }}
$$

274 where $P_{i-1}$ is the power demanded by berthed ships at the 275 previous time, $P_{\text {arr }}$ is the power demanded by ships that arrive 276 to the port, and $P_{\text {dep }}$ is the power demanded by ships that depart 277 from the port. The power requirements of each ship type are 278 given in Table I. Table II shows that the per-hour average power 279 demanded by berthed ships is $221.9 \mathrm{MW}$, which is the value to 280 be used for sizing the proposed renewable energies-based cold 281 ironing system.

\section{Wind and Solar Resources}

Table III (obtained from [51], [52]) shows the average daily wind speed $\left(v_{w}\right)$ and the average daily irradiation per square meter $(H)$ at the port of Barcelona, whose geographical coordinates are $41^{\circ} 20^{\prime} 42^{\prime \prime} \mathrm{N}$ and $2^{\circ} 08^{\prime} 30^{\prime \prime} \mathrm{E}$. The wind speed has been obtained from the database [51], assuming a WT height of $8100 \mathrm{~m}$, whereas the solar irradiation has been obtained from the 9 database [52], assuming an optimal inclination of the PV panels that corresponds to the latitude at port of Barcelona $-5^{\circ}$.
With respect to the wind resource, in order to obtain the 291 extracted power from the wind, the following expression can be 292 used [53]:

$$
P_{w}=\frac{1}{2} \rho c_{p} A v_{w}^{3}
$$

where $\rho=1.225 \mathrm{~kg} / \mathrm{m}^{3}$ is the air density at sea level (assuming 294 the normal temperature $T=298 \mathrm{~K}), c_{p}$ is the power coefficient 295 of the WT, $A=\pi R^{2}$ is the area swept by the rotor $(R=$ blade's 296 length), and $v_{w}$ is the wind speed. Assuming that there exists an 297 MPPT algorithm [54] that allows the WT to obtain the maximum 298 power from a given wind speed, then the Betz's limit [55] can 299 be used as the maximum power coefficient of the WT, i.e., 300 $c_{p}=0.593$. Assuming the WT V150-4.2 MW from Vestas [56], 301 whose rotor diameter is $150 \mathrm{~m}$, it means that its radius (or blade's 302 length) is $75 \mathrm{~m}$. According to all the aforementioned values, the 303 extracted power from the wind (2) for the average wind speed 304 at the port of Barcelona $(5.28 \mathrm{~m} / \mathrm{s})$ corresponds to $944.8 \mathrm{~kW}, 305$ which is also shown in Table III. 306

Regarding the solar resource, the peak sun-hours (PSH) of the 307 PV panel can be obtained by dividing the average irradiation per 308 square meter at the port of Barcelona $\left(H=5.64 \mathrm{kWh} / \mathrm{m}^{2}\right)$ by 309 the theoretical irradiance that a PV panel would receive under 310 normal meteorological conditions (i.e., with no clouds in the 311 sky, with the sun directly overhead, etc.), which corresponds to 312 of $1000 \mathrm{~W} / \mathrm{m}^{2}$ [57]. Therefore

$$
\mathrm{PSH}=H / 1000
$$

giving a result of $\mathrm{PSH}=5.64 \mathrm{~h}$, as shown in Table III.

\section{Required Number of WTs and PV Panels}

Considering that a WT delivers much more power than a 316 PV panel, then WTs will satisfy the highest power demand 317 from ships at berth. As a result, $3 / 4$ (or $75 \%$ ) of the demanded 318 power (221.9 MW according to Table II) is assumed to be 319 supplied by WTs, giving a value of $166.42 \mathrm{MW}$. As stated in 320 Section III-C, a WT can extract $944.8 \mathrm{~kW}$ from the wind. As- 321 suming no mechanical losses and no electrical losses in the WT, 322 the (output) electrical power equals the (input) wind power, i.e., 323 $944.8 \mathrm{~kW}$. Then, the required number of WTs $\left(N_{W T}\right)$ can be 324 easily obtained as follows:

$$
N_{\mathrm{WT}}=\text { Power demanded by ships/WT power }
$$


TABLE II

Hourly Electrical Demand (Power) From Berthed Ships at the Port of Barcelona for One Week (AdAPted From [49] ANd [50])*

\begin{tabular}{|c|c|c|c|c|c|c|c|c|c|c|c|c|c|c|c|}
\hline \multirow[b]{2}{*}{ Time } & \multicolumn{2}{|c|}{ Day 1} & \multicolumn{2}{|c|}{ Day 2} & \multicolumn{2}{|c|}{ Day 3} & \multicolumn{2}{|c|}{ Day 4} & \multicolumn{2}{|c|}{ Day 5} & \multicolumn{2}{|c|}{ Day 6} & \multicolumn{2}{|c|}{ Day 7} & \multirow{2}{*}{$\begin{array}{l}\text { Average } \\
\text { power } \\
(\mathrm{MW})\end{array}$} \\
\hline & $\begin{array}{l}\text { Arriv./ } \\
\text { Depart. }\end{array}$ & $\begin{array}{l}\text { Power }^{* *} \\
\text { (MW) }\end{array}$ & $\begin{array}{l}\text { Arriv./ } \\
\text { Depart. }\end{array}$ & $\begin{array}{l}\text { Power } \\
\text { (MW) }\end{array}$ & $\begin{array}{l}\text { Arriv./ } \\
\text { Depart. }\end{array}$ & $\begin{array}{l}\text { Power } \\
\text { (MW) }\end{array}$ & $\begin{array}{l}\text { Arriv./ } \\
\text { Depart. }\end{array}$ & $\begin{array}{l}\text { Power } \\
\text { (MW) }\end{array}$ & $\begin{array}{l}\text { Arriv./ } \\
\text { Depart. }\end{array}$ & $\begin{array}{l}\text { Power } \\
\text { (MW) }\end{array}$ & $\begin{array}{l}\text { Arriv./ } \\
\text { Depart. }\end{array}$ & $\begin{array}{l}\text { Power } \\
\text { (MW) }\end{array}$ & $\begin{array}{l}\text { Arriv./ } \\
\text { Depart. }\end{array}$ & $\begin{array}{l}\text { Power } \\
\text { (MW) }\end{array}$ & \\
\hline $0 \mathrm{~h}$ & $0 / 0$ & $132.5^{* * *}$ & $0 / 0$ & 219.0 & $0 / 0$ & 199.1 & $1^{3} / 0$ & 213.4 & $1^{1} / 1^{1}$ & 232.6 & $0 / 0$ & 211.4 & $0 / 1^{3}$ & 261.9 & 210.0 \\
\hline $1 \mathrm{~h}$ & $0 / 0$ & 132.5 & $0 / 0$ & 219.0 & $0 / 1^{1}$ & 191.6 & $1^{3} / 0$ & 219.9 & $1^{1 / 0}$ & 240.1 & $0 / 0$ & 211.4 & $0 / 1^{1}$ & 254.4 & 209.8 \\
\hline $2 \mathrm{~h}$ & $1^{1 / 0}$ & 140.0 & $0 / 0$ & 219.0 & $0 / 0$ & 191.6 & $0 / 0$ & 219.9 & $0 / 1^{1,3}$ & 226.1 & $1^{1 / 0}$ & 218.9 & $0 / 0$ & 254.4 & 210.0 \\
\hline $3 \mathrm{~h}$ & $0 / 0$ & 140.0 & $0 / 0$ & 219.0 & $0 / 0$ & 191.6 & $1^{3} / 0$ & 226.4 & $1^{1 / 1} 1^{3}$ & 227.1 & $0 / 0$ & 218.9 & $1^{1,3} / 0$ & 268.4 & 213.1 \\
\hline $4 \mathrm{~h}$ & $0 / 0$ & 140.0 & $1^{1 / 0}$ & 226.5 & $0 / 0$ & 191.6 & $1^{2,3} / 1^{1}$ & 232.6 & $0 / 1^{1}$ & 219.6 & $0 / 0$ & 218.9 & $0 / 0$ & 268.4 & 213.9 \\
\hline $5 \mathrm{~h}$ & $0 / 0$ & 140.0 & $0 / 0$ & 226.5 & $0 / 0$ & 191.6 & $1^{3} / 0$ & 239.1 & $1^{2,3} / 1^{1}$ & 225.8 & $0 / 0$ & 218.9 & $1^{1} / 0$ & 275.9 & 216.8 \\
\hline $6 \mathrm{~h}$ & $0 / 0$ & 140.0 & $2^{1 / 0}$ & 241.5 & $1^{1 /} / 1^{1}$ & 191.6 & $1^{1} / 1^{1}$ & 239.1 & $1^{1 / 0}$ & 233.3 & $1^{3 / 0}$ & 225.4 & $0 / 0$ & 275.9 & 221.0 \\
\hline $7 \mathrm{~h}$ & $0 / 0$ & 140.0 & $0 / 0$ & 241.5 & $0 / 0$ & 191.6 & $1^{1,3} / 0$ & 253.1 & $0 / 0$ & 233.3 & $1^{1 / 0}$ & 232.9 & $0 / 0$ & 275.9 & 224.0 \\
\hline $8 \mathrm{~h}$ & $0 / 0$ & 140.0 & $0 / 0$ & 241.5 & $1^{3} / 0$ & 198.1 & $1^{1 /} / 1^{1}$ & 253.1 & $1^{2} / 0$ & 240.5 & $2^{1 / 0}$ & 247.9 & $1^{3} / 0$ & 282.4 & 229.1 \\
\hline $9 \mathrm{~h}$ & $1^{2} / 0$ & 147.2 & $0 / 0$ & 241.5 & $0 / 0$ & 198.1 & $0 / 0$ & 253.1 & $0 / 1^{1}$ & 233.0 & $0 / 0$ & 247.9 & $0 / 1^{2}$ & 275.2 & 228.0 \\
\hline $10 \mathrm{~h}$ & $1^{2} / 0$ & 154.4 & $0 / 0$ & 241.5 & $1^{1,2} / 0$ & 212.8 & $1^{2} / 1^{2}$ & 253.1 & $0 / 0$ & 233.0 & $0 / 0$ & 247.9 & $0 / 0$ & 275.2 & 231.1 \\
\hline $11 \mathrm{~h}$ & $0 / 0$ & 154.4 & $0 / 1^{2}$ & 234.3 & $0 / 1^{1}$ & 205.3 & $2^{1}, 1^{2,3} / 1^{3}$ & 275.3 & $1^{1,3} / 0$ & 247.0 & $0 / 0$ & 247.9 & $0 / 2^{1}$ & 260.2 & 232.1 \\
\hline $12 \mathrm{~h}$ & $1^{2} / 0$ & 161.6 & $0 / 0$ & 234.3 & $2^{1}, 1^{3} / 1^{2}$ & 219.6 & $0 / 1^{1}$ & 267.8 & $1^{1,3} / 1^{1,2}$ & 246.3 & $0 / 2^{1}$ & 232.9 & $0 / 0$ & 260.2 & 231.8 \\
\hline $13 \mathrm{~h}$ & $1^{1 / 0}$ & 169.1 & $0 / 0$ & 234.3 & $0 / 1^{3}$ & 213.1 & $0 / 0$ & 267.8 & $0 / 2^{2}, 1^{3}$ & 225.4 & $0 / 0$ & 232.9 & $1^{2} / 1^{3}$ & 260.9 & 229.1 \\
\hline $14 \mathrm{~h}$ & $0 / 0$ & 169.1 & $0 / 1^{1}$ & 226.8 & $0 / 1^{2}$ & 205.9 & $0 / 2^{3}$ & 254.8 & $1^{3} / 0$ & 231.9 & $1^{1 / 1} 1^{1}$ & 232.9 & $0 / 0$ & 260.9 & 226.0 \\
\hline $15 \mathrm{~h}$ & $0 / 0$ & 169.1 & $0 / 1^{2}$ & 219.6 & $0 / 0$ & 205.9 & $1^{1 /} / 1^{3}$ & 255.8 & $0 / 0$ & 231.9 & $0 / 0$ & 232.9 & $0 / 2^{3}$ & 247.9 & 223.3 \\
\hline $16 \mathrm{~h}$ & $1^{1 / 0}$ & 176.6 & $2^{1 /} / 1^{1}$ & 227.1 & $0 / 0$ & 205.9 & $0 / 0$ & 255.8 & $1^{2} / 1^{1}$ & 231.6 & $0 / 0$ & 232.9 & $0 / 0$ & 247.9 & 225.4 \\
\hline $17 \mathrm{~h}$ & $0 / 0$ & 176.6 & $0 / 1^{1,3}$ & 213.1 & $1^{2} / 1^{3}$ & 206.6 & $1^{3} / 1^{2}$ & 255.1 & $1^{1 / 1} 1^{3}$ & 232.6 & $0 / 0$ & 232.9 & $0 / 0$ & 247.9 & 223.5 \\
\hline $18 \mathrm{~h}$ & $0 / 0$ & 176.6 & $0 / 1^{3}$ & 206.6 & $0 / 1^{2}$ & 199.4 & $0 / 1^{1}$ & 247.6 & $1^{1 /} / 0$ & 240.1 & $1^{1 / 0}$ & 240.4 & $0 / 0$ & 247.9 & 222.7 \\
\hline $19 \mathrm{~h}$ & $0 / 0$ & 176.6 & $0 / 0$ & 206.6 & $0 / 0$ & 199.4 & $0 / 1^{1,2}$ & 232.9 & $0 / 1^{1,3}$ & 226.1 & $1^{1 / 0}$ & 247.9 & $0 / 1^{1}$ & 240.4 & 218.6 \\
\hline $20 \mathrm{~h}$ & $1^{1}, 2^{2} / 0$ & 198.5 & $0 / 1^{1}$ & 199.1 & $0 / 0$ & 199.4 & $0 / 0$ & 232.9 & $0 / 1^{1}$ & 218.6 & $1^{3} / 0$ & 254.4 & $0 / 1^{3}$ & 233.9 & 219.5 \\
\hline $21 \mathrm{~h}$ & $1^{1,3} / 0$ & 212.5 & $0 / 0$ & 199.1 & $0 / 0$ & 199.4 & $1^{2} / 1^{1}$ & 232.6 & $0 / 0$ & 218.6 & $0 / 0$ & 254.4 & $1^{1} / 1^{1}$ & 233.9 & 221.5 \\
\hline $22 \mathrm{~h}$ & $1^{3} / 0$ & 219.0 & $0 / 0$ & 199.1 & $0 / 0$ & 199.4 & $0 / 0$ & 232.6 & $0 / 0$ & 218.6 & $0 / 1^{1}$ & 246.9 & $0 / 1^{1}$ & 226.4 & 220.3 \\
\hline $23 \mathrm{~h}$ & $0 / 0$ & 219.0 & $0 / 0$ & 199.1 & $1^{1 /} / 0$ & 206.9 & $0 / 0$ & 232.6 & $0 / 1^{2}$ & 211.4 & $2^{1}, 1^{3} / 0$ & 268.4 & $1^{1,3} / 1^{3}$ & 233.9 & 224.5 \\
\hline & & & & & & & & & & & & 101 & rage & er (MW) & 221.9 \\
\hline
\end{tabular}

Notes:

1,2,3 Superscripts 1,2 and 3 stand for the ship type: 1 = Container; 2 = Tanker (including LNG carrier); and $3=$ RoRo. Their corresponding power requirements are given in Table I.

* All data corresponds to cargo merchant ships that arrive to / depart from the port of Barcelona for 1 week. Sources: [49]-[50] and confidential data from the Authority of the Port of Barcelona.

${ }^{* *}$ The power demanded by berthed ships at the port of Barcelona has been calculated as: $P_{\mathrm{i}}=P_{\mathrm{i}-1}+P_{\text {arr }}-P_{\text {dep }}$ (where $P_{\mathrm{i}}$ is the power demanded by berthed ships at the current time; $P_{\mathrm{i}-1}$ is the power demanded by berthed ships at the previous time; $P_{\text {arr }}$ is the power demanded by ships that arrive to the port; and $P_{\text {dep }}$ is the power demanded by ships that depart from the port).

*** Albeit no arrivals and departures, there were 18 berthed ships at the port of Barcelona on Day 0 at 23:59h. Among them, 12 ships were containers, 5 ships were tankers and 1 ship was a RoRo. It gives an overall value of $132.5 \mathrm{MW}$ of demanded power (according to the ships' power requirements in Table I), which is the initial condition for this study.

327 With respect to PV panels, they will satisfy $1 / 4$ (or $25 \%$ ) of 328 the demanded power, which corresponds to 55.47 MW. As this 329 corresponds to the hourly average power, the energy demanded 330 by berthed ships to be supplied by PV panels will be $55.47 \mathrm{MWh}$. 331 The required number of PV panels $\left(N_{\mathrm{PV}}\right)$ can be easily obtained 332 as follows:

$$
N_{\mathrm{PV}}=E_{T} /\left(V_{\mathrm{MPP}} I_{\mathrm{MPP}} \operatorname{PSH} \eta\right)
$$

333 where $E_{T}$ is the energy demand (55.47 MWh), PSH $=5.64 \mathrm{~h}$ 334 (see Table III), $\eta$ is the PV panel efficiency (usually around $33590 \%$, i.e., $\eta=0.9)$ and $V_{\mathrm{MPP}}$ and $I_{\mathrm{MPP}}$ are the voltage and 336 the current at the maximum power point, respectively. Assum337 ing the monocrystalline 144-cell module STP375S-24/Vfh from
Suntech [58], its maximum power point voltage and current are 338 $39.9 \mathrm{~V}$ and $9.4 \mathrm{~A}$, respectively. Then, taking into account the 339 aforementioned values and according to (5), the following num- 340 ber of PV panels would be required: $29137 \mathrm{PV}$ panels.

341

\section{E. Proposed Cold Ironing Topology}

The proposed cold ironing topology for the smart port of 343 Barcelona consists of three main parts, as depicted in Fig. 3. 344

First, the offshore wind farm (left side of Fig. 3) is based 345 on a set of DFIG-based WTs $\left(\mathrm{WT}_{1} \ldots \mathrm{WT}_{n}\right)$ (including their 346 corresponding gearbox and a back-to-back converter, where a 347 battery bank is connected to the dc link through a chopper, and a 348 filter is connected at the inverter's output to reduce harmonics), 349 


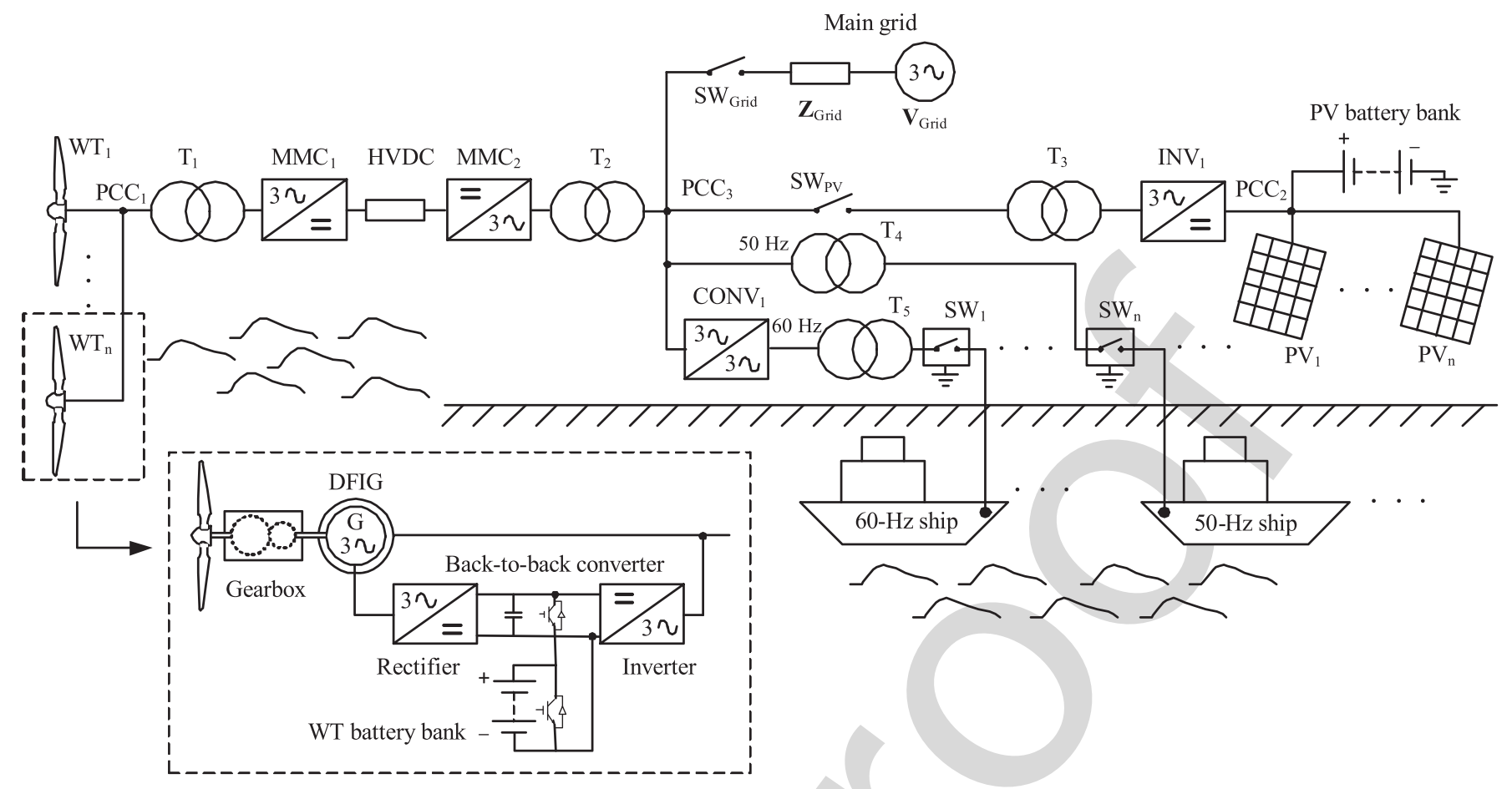

Fig. 3. Proposal of a renewable energies-based cold ironing system for a smart port microgrid (particularized for the port of Barcelona). Single-line diagram.

TABLE III

DAILY WIND AND SOLAR RESOURCES AT THE PORT OF BARCELONA (OBTAINED FROM [51] AND [52])

\begin{tabular}{cccc}
\hline \hline \multicolumn{2}{c}{ Wind resource } & \multicolumn{2}{c}{ Solar resource } \\
$\nu_{\mathrm{w}}(\mathrm{m} / \mathrm{s})^{*}$ & $P_{\mathrm{w}}(\mathrm{kW})$ & $H\left(\mathrm{kWh} / \mathrm{m}^{2}\right)^{* *}$ & $P S H(\mathrm{~h})$ \\
\hline 5.28 & 944.8 & 5.64 & 5.64 \\
\hline \hline
\end{tabular}

${ }^{*}$ Obtained from [51] assuming a WT height of 100 meters.

** Obtained from [52] assuming a PV inclination of 36 degrees

which are connected to a point of common coupling $\left(\mathrm{PCC}_{1}\right)$; an off-shore-side step-up transformer $\left(T_{1}\right)$ to increase the voltage level in order to transmit it to the shore-side installation; an HVdc transmission system, which consists of a rectifier unit (off-shore side) based on an MMC (MMC 1 ), a dc line and an inverter unit (shore side) with another $\mathrm{MMC}\left(\mathrm{MMC}_{2}\right)$; finally, a shore-side step-down transformer $\left(T_{2}\right)$ reduces the voltage level in order to adapt it to the voltage requirements. This topology corresponds to the usual approach when modeling HVdc systems for offshore wind farms [59].

Second, the PV farm (right side of Fig. 3) consists of: a set of PV panels $\left(\mathrm{PV}_{1} \ldots \mathrm{PV}_{n}\right.$; including their load regulators), which are connected to a point of common coupling $\left(\mathrm{PCC}_{2}\right)$; a battery bank connected to $\mathrm{PCC}_{2}$ in order to reduce power swings; a three-phase inverter ( $\mathrm{INV}_{1}$; with its filter) in order to transform the dc variables provided by the PV panels to the required three-phase ac variables with no harmonics; and a stepup transformer $\left(T_{3}\right)$ with the aim of increasing the voltage level to adapt it to the port microgrid's voltage requirements. This topology corresponds to the usual approach when modeling PV power plants [60]. The $\mathrm{PV}$ farm is connected to the $\mathrm{PCC}_{3}$ by means of the switch $\mathrm{SW}_{\mathrm{PV}}$. Note that both WT and PV plants are linked by means of the point of common connection $\mathrm{PCC}_{3}, 372$ so they must be properly controlled and synchronized in order to 373 provide the same RMS voltages with equal phase angle and the 374 same frequency, which can be achieved by choosing a proper 375 PLL, such as the well-known three-phase PLL described in [61]. 376

Finally, the installation that adapts the phase-to-phase voltage 377 and the frequency that comes from the renewable energies to the 378 ones required by the ships is depicted in the center of Fig. 3. It 379 consist of two different parts, depending on the frequency level: 380 One part works at $50 \mathrm{~Hz}$ (which is the frequency that inject 381 both WTs and PV panels), so no additional power converter 382 is needed, whereas another part works at $60 \mathrm{~Hz}$, so a three- 383 phase ac/ac power converter $\left(\mathrm{CONV}_{1}\right)$ is needed to obtain that 384 frequency from the generated one $(50 \mathrm{~Hz})$. Both parts need a 385 transformer $\left(T_{4}\right.$ and $T_{5}$, respectively) to adapt the phase-to- 386 phase voltage to the ship's requirements, according to Table I. 387 Finally, switchboards $\left(\mathrm{SW}_{1} \ldots \mathrm{SW}_{n}\right)$, are needed in order to 388 physically connect the electrical system of the ship to the shore- 389 side installation, as explained in Section II (Fig. 1). 390

It should be noted that under certain circumstances, not all the 391 power demanded by berthed ships could be satisfied. For exam- 392 ple, at night, there is no Sun and the batteries associated with PV 393 panels could not satisfy the $25 \%$ of the demand during all night 394 hours. Under these (or other similar) circumstances, the power 395 that cannot be satisfied from renewable energies must necessar- 396 ily come from the main grid. As a result, the main grid (modelled 397 as a voltage source and a series impedance) could be connected 398 at $\mathrm{PCC}_{3}$ through the switch $\mathrm{SW}_{\text {Grid }}$, as shown in Fig. 3.

\section{F. Study Cases}

The proposed renewable energies-based cold ironing sys- 401 tem for the port of Barcelona has been simulated with 402 


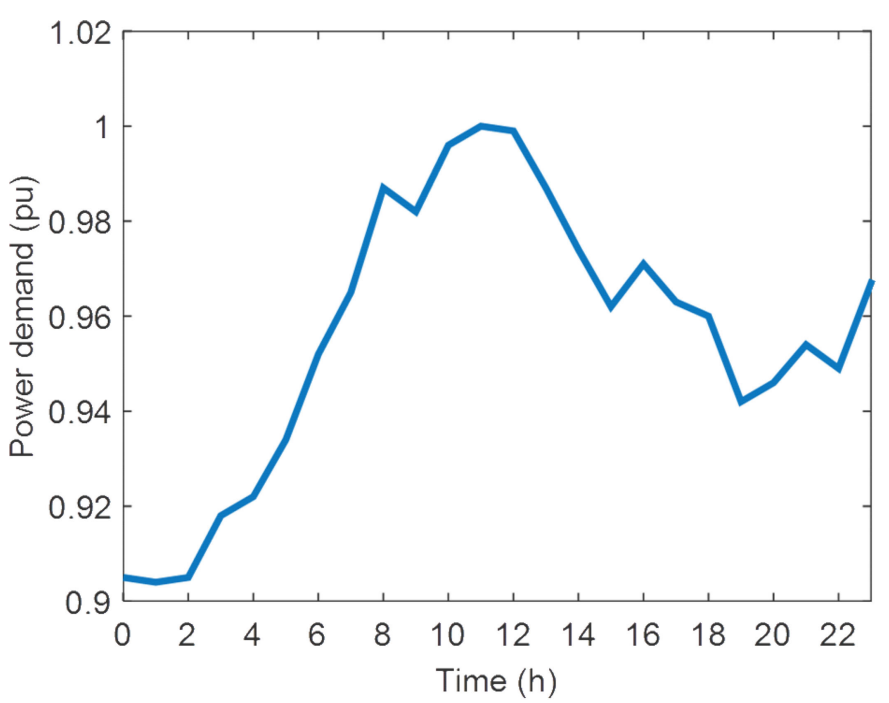

(a)

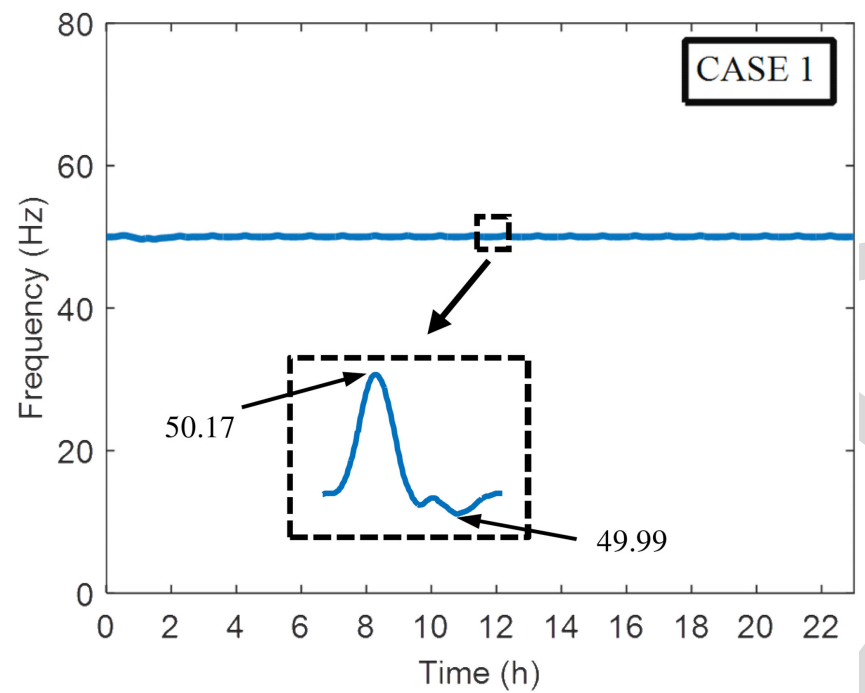

(b)

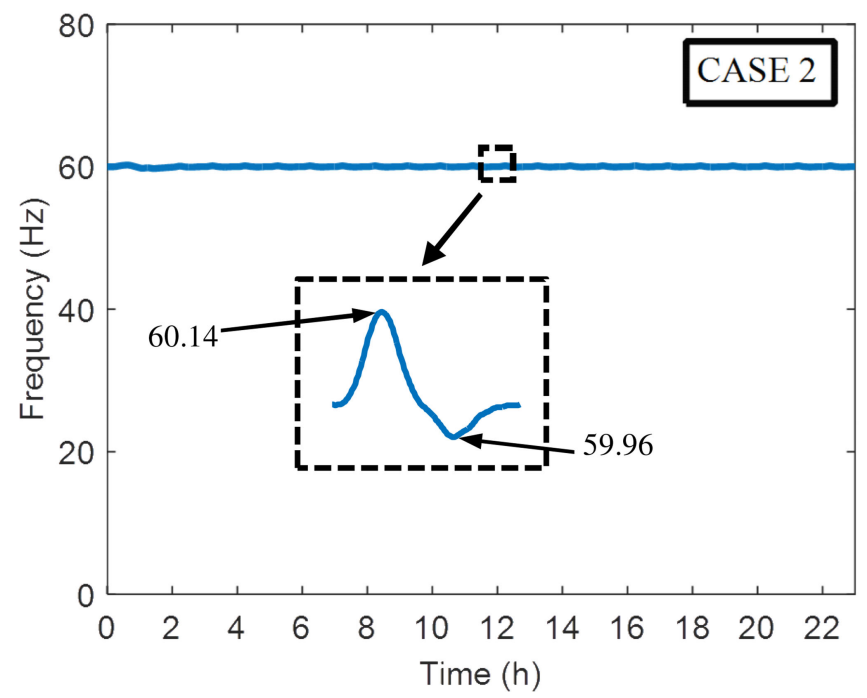

(c)

Fig. 4. Stability of the proposed renewable energies-based cold ironing system at the port of Barcelona. (a) Pattern of power demanded by berthed ships for a day. (b) Frequency response to the load change considering $50-\mathrm{Hz}$ ships (case 1). (c) Frequency response to the load change considering $60-\mathrm{Hz}$ ships (case 2). Frequency corresponds to voltage obtained by simulation at $\mathrm{PCC}_{3}$ in Fig. 3.
TABLE IV

REQUiRED Number of WTS AND PV PANELS to SATISFY THE PER-Hour DEMANDED POWER By BERTHEd SHIPS AT THE PORT OF BARCELONA

\begin{tabular}{llll}
\hline \hline Time & ${\text { Power }(\mathrm{pu})^{*}}^{*}$ & Number of WTs & Number of PV panels \\
\hline $0 \mathrm{~h}$ & 0.905 & 167 & 27,577 \\
$1 \mathrm{~h}$ & 0.904 & 167 & 27,551 \\
$2 \mathrm{~h}$ & 0.905 & 167 & 27,577 \\
$3 \mathrm{~h}$ & 0.918 & 170 & 27,984 \\
$4 \mathrm{~h}$ & 0.922 & 170 & 28,089 \\
$5 \mathrm{~h}$ & 0.934 & 173 & 28,470 \\
$6 \mathrm{~h}$ & 0.952 & 176 & 29,021 \\
$7 \mathrm{~h}$ & 0.965 & 178 & 29,415 \\
$8 \mathrm{~h}$ & 0.987 & 182 & 30,085 \\
$9 \mathrm{~h}$ & 0.982 & 181 & 29,940 \\
$10 \mathrm{~h}$ & 0.996 & 184 & 30,348 \\
$11 \mathrm{~h}$ & 1.000 & 185 & 30,479 \\
$12 \mathrm{~h}$ & 0.999 & 185 & 30,439 \\
$13 \mathrm{~h}$ & 0.987 & 182 & 30,085 \\
$14 \mathrm{~h}$ & 0.974 & 180 & 29,678 \\
$15 \mathrm{~h}$ & 0.962 & 178 & 29,323 \\
$16 \mathrm{~h}$ & 0.971 & 179 & 29,599 \\
$17 \mathrm{~h}$ & 0.963 & 178 & 29,350 \\
$18 \mathrm{~h}$ & 0.960 & 177 & 29,245 \\
$19 \mathrm{~h}$ & 0.942 & 174 & 28,706 \\
$20 \mathrm{~h}$ & 0.946 & 175 & 28,824 \\
$21 \mathrm{~h}$ & 0.954 & 176 & 29,087 \\
$22 \mathrm{~h}$ & 0.949 & 175 & 179,481 \\
$23 \mathrm{~h}$ & 0.967 & 179 & \\
\hline \hline
\end{tabular}

Notes:

* Power is given in per unit (pu) assuming that the base power is the highest power value given in the rightmost column of Table II, i.e., 232.1 MW.

${ }^{* *}$ According to (4), assuming that WTs satisfy $75 \%$ of power demand.

${ }^{* * *}$ According to (5), assuming that PV panels satisfy $25 \%$ of power demand.

MATLAB-Simulink. It has been assumed that WTs provide 75\% 403 of the energy demanded by ships, whereas PV panels provide 404 $25 \%$, as stated in Section III-D. It has also been assumed that the 405 ships' voltage requirement corresponds to the most unfavorable 406 phase-to-phase value, i.e., $11 \mathrm{kV}$ according to Table I. $\quad 407$

A load change (i.e., the power demanded by ships at berth) has 408 been programmed for a day according to the per-time demanded 409 power given in the rightmost column of Table II, whose profile is 410 shown in Fig. 4(a). The required number of WTs and PV panels 411 to provide the per-hour demanded power is shown in Table IV, 412 whose values have been calculated according to (4) and (5), 413 respectively. The average values are 177 WTs and 29137 PV 414 panels, which correspond to the ones calculated in Section III-D. 415

The following cases have been studied.

1) Case 1: $50-\mathrm{Hz}$ load change, i.e., power demanded by 417 50-Hz ships according to the pattern shown in Fig. 4(a). 418 
2) Case 2: 60-Hz load change, i.e., power demanded by 60-Hz ships according to the pattern shown in Fig. 4(a).

Fig. 4(b) and (c) depicts the simulated frequency at the point of common connection between the wind farm and the PV farm ( $\mathrm{PCC}_{3}$ in Fig. 3) for the aforementioned two cases. The frequency has been obtained by means of a PLL [61]. The issue of voltage and frequency fluctuations due to load changes is a well-known problem [62]. Apparently, the simulated system has no problems of frequency oscillations, as the frequency remains constant during all the entire day. However, if a zoom is made in the time instants when the load suddenly increases or decreases (e.g., at $12 \mathrm{~h}$ ), a frequency fluctuation is observed. However, this oscillation is not critical, as the depicted minimum and maximum values of frequency are close to the corresponding steady-state values for each case. Nevertheless, if the problem of frequency fluctuation were to be tackled, a PSS or an FACT could be used [63], which is out of the scope of this paper.

\section{CONCLUSION}

First, this work has stated the importance of cold ironing systems in order to reduce the GHGs emissions from berthed ships, which are harmful for both atmosphere and human health. The electrical requirements of docked vessels, the current regulations on cold ironing, the concept of smart ports as a microgrid, and examples of current ports that make use of cold ironing systems have been given.

Second, the power demanded by ships that are berthed at the port of Barcelona and the available wind and solar resources on that place have been analyzed in order to propose a proper cold ironing system based on renewable energies, focusing the attention on the use of wind turbines and photovoltaic panels to satisfy the ships' power demand. The proposed cold ironing topology has envisioned that $75 \%$ of power demanded by berthed ships is supplied by offshore WTs, whereas $25 \%$ is supplied by PV panels. The proposed system has been simulated in MATLAB-Simulink assuming two cases in which the power demanded by berthed ships varies through a day. The simulations have revealed that the proposed renewable energies-based cold ironing system is stable, as there are no noticeable frequency fluctuations.

To sum up, cold ironing systems are absolutely necessary to reduce GHGs emissions from berthed ships, and the technology based on renewable energies appears to be a plausible solution, according to the results shown in this paper particularized for the port of Barcelona. This paper tried to shed some light into the problem, but more studies need to be performed to make it possible.

The authors would like to thank the Authority of the Port of Barcelona for delivering us the data concerning arrivals and departures during one week classified by ship types.

[1] G. N. Tiwari and R. K. Mishra, Advanced Renewable Energy Sources. Royal Soc. Chem. Publ.: Cambridge, U.K., 2012, pp. 9-10.

[2] J. Twidell and T. Weir, Renewable Energy Resources, 2nd ed. New York, NY, USA: Taylor \& Francis, 2006, pp. 2-4.
[3] C. A. Pope et al., "Lung cancer, cardiopulmonary mortality, and long-term 474 exposure to fine particulate air pollution," J. Amer. Med. Assoc., vol. 287, 475 no. 9, pp. 1132-1141, Mar. 2002.

[4] International Maritime Organization (IMO), "Third IMO greenhouse gas 477 study 2014-Executive summary and final report," IMO, London, U.K., 478 Tech. Rep., Oct. 2015, Accessed: Dec. 14, 2018. [Online]. Available: 479 http://www.imo.org/en/OurWork/Environment/PollutionPrevention/ 480 AirPollution/Documents/Third\%20Greenhouse\%20Gas\%20Study/ 481 GHG3\%20Executive\%20Summary\%20and\%20Report.pdf 482

[5] Transport \& Environment (TE), "Air pollution from ships," TE, Brus- 483 sels, Belgium. Accessed: Dec. 14, 2018. [Online]. Available: https://www. 484 transportenvironment.org/what-we-do/shipping/air-pollution-ships 485

[6] J. J. Corbet, C. Wang, J. J. Winebrake, and E. Green, "Allocation and fore- 486 casting of global ship emissions," Clean Air Task Force, USA. Tech. Rep., 487 Jan. 2007. Accessed: Dec. 14, 2018. [Online]. Available: https://www. 488 researchgate.net/publication/241579973_Allocation_and_Forecasting_ 489 of_Global_Ship_Emissions 490

[7] V. Eyring, H. W. Köhler, J. V. Aardenne, and A. Lauer, "Emissions from 491 international shipping: 1. The last 50 years," J. Geophys. Res., vol. 110, 492 no. D17, pp. 1-12, Sep. 2005.

[8] P. G. Theodoros, "A cold ironing study on modern ports, implementation 494 and benefits thriving for worldwide ports," Ph.D. dissertation, School 495 of Naval Arch. \& Marine Eng. National Tech. Univ., Athens, Greece, 496 2012. 497

[9] The Marine Environment Protection Committee (MEPC) - International 498 Maritime Organization (IMO). Resolution MEPC.176 (58) adopted on 499 10 October 2008, "Amendments to the annex of the protocol of 1997500 to amend the international convention for the prevention of pollution 501 from ships, 1973, as modified by the protocol of 1978 relating thereto 502 (Revised MARPOL Annex VI)," MEPC-IMO. Accessed: Dec. 14, 2018. 503 [Online]. Available: https://www.epa.gov/sites/production/files/2016-09/ 504 documents/resolution-mepc-202-62-7-15-2011.pdf

[10] J. Faber, D. Nelissen, G. Hon, H. Wang, and M. Tsimplis, "Regulated slow 506 steaming in maritime transport-An assessment of options, costs and 507 benefits," The International Council on Clean Transportation \& CE Delft, 508 Tech. Rep., Feb. 2012. Accessed: Dec. 14, 2018. [Online]. Available: 509 https://www.theicct.org/sites/default/files/publications/CEDelft_slow_ 510 steaming 2012.pdf 511

[11] N. Olmer, B. Comer, B. Roy, X. Mao, and D. Rutherford, "Greenhouse 512 gas emissions from global shipping, 2013-2015," The International 513 Council on Clean Transportation, Tech. Rep., Oct. 2017, Accessed: Dec. 514 14, 2018. [Online]. Available: https://www.theicct.org/sites/default/files/ 515 publications/Global-shipping-GHG-emissions-2013-2015_ICCT-Report_ 516 17102017_vF.pdf

[12] T. Smith et al., " $\mathrm{CO}_{2}$ emissions from international shipping-Possible 518 reduction targets and their associated pathways," Univ. Maritime Advi- 519 sory Services, London, UK, Tech. Rep., Oct. 2016. Accessed: Jan. 11, 520 2019. [Online]. Available: https://u-mas.co.uk/LinkClick.aspx?fileticket 521 $=$ na3ZeJ8Vp1Y\%3D\&portalid $=0 \quad 522$

[13] J. J. Corbett and H. W. Koehler, "Updated emissions from ocean shipping," 523 J. Geophys. Res., vol. 108, no. D20, pp. 1-16, Oct. 2003.

[14] H. T. Katen and R. Borstlap, Ships' Electrical Systems. Vlissingen, The 525 Netherlands: Dokmar Maritime PubL., 2011, pp. 29-33. 526

[15] C. Chryssakis, "Future fuels for shipping-Pathways to 2050," Det 527 Norske Veritas (DNV), Oslo, Norway, Mar. 2015. Accessed: Jan. 11, 528 2019. [Online]. Available: https://tapahtumat.tekes.fi/uploads/f29c2613/ 529 Christos_Chryssakis-8065.pdf

[16] E. A. Sciberras, B. Zahawi, and D. J. Atkinson, "Electrical characteristics 531 of cold ironing energy supply for berthed ships," Transp. Res. Part D, 532 Transp. Environ., vol. 39, pp. 31-43, Aug. 2015. 533

[17] D. Paul and V. Haddadian, "Cold ironing-Power system grounding and 534 safety analysis," in Proc. IEEE Ind. Appl. Soc. Annu. Meeting, Howloon, 535 China, Oct. 2005, pp. 1503-1511.

[18] R. Fiadomor, "Assessment of alternative maritime power (cold ironing) 537 and its impact on port management and operations," Ph.D. dissertation, 538 World Maritime Univ., Malmö, Sweden, 2009.

[19] A. Cuculic, D. Vucetic, and V. Tomas, "High voltage shore connection," 540 in Proc. IEEE Int. Symp. Croatian Soc. Electron. Marine, Zadar, Croatia, 541 Sep. 2011, pp. 257-259. 542

[20] G. Sulligoi, D. Bosich, R. Pelaschiar, G. Lipardi, and F. Tosato, 543 "Shore-to-ship power," Proc. IEEE, vol. 103, no. 12, pp. 2381-2400, 544 Dec. 2015.

[21] N. Nikitakos, "Green logistics_-The concept of zero emissions port," FME 546 Trans., vol. 40, no. 4, pp. 201-206, Dec. 2012

[22] Y. Khersonsky, M. Islam, and K. Peterson, "Challenges of connecting 548 shipboard marine systems to medium voltage shoreside electrical power," 549 IEEE Trans. Ind. Appl., vol. 43, no. 3, pp. 838-844, May/Jun. 2007. 
[23] D. Bailey et al., "Harboring pollution-Strategies to clean up U.S. Ports," Natural Resources Defense Council, New York, NY, USA, Tech. Rep., Aug. 2014. Accessed: Jan. 11, 2019. [Online]. Available: https://www.nrdc.org/sites/default/files/ports2.pdf

[24] D. Paul, K. Peterson, and P. R. Chavdarian, "Designing cold ironing power systems-Electrical safety during ship berthing," IEEE Ind. Appl. Mag., vol. 20, no. 3, pp. 24-32, May/Jun. 2014.

[25] Schneider Electric Industries, "ShoreBoXTM: Shore connection for ships at Berth-Plug into green power," Schneider Electric Industries SAS, Rueil-Malmaison, France, Tech. Brochure, Jul. 2015. Accessed: Jan. 11, 2019. [Online]. Available: https://www.schneiderelectric.com/en/download/document/998-3606_GMA-GB/

26] Det Norske Veritas (DNV), "Emissions from ships operating in the greater metropolitan area," DNV, North Sydney, NSW, Australia, Tech. Rep., Jun. 2015. Accessed: Jan. 11, 2019. [Online]. Available: https://www.epa. nsw.gov.au/ /media/EPA/Corporate\%20Site/resources/air/gma-shipemissions.ashx

[27] S. E. Sanes, P. Casals-Torrens, R. Bosch-Tous, and M. Castells, "Comparative analysis of cold ironing rules," Nase More, vol. 64, no. 3, pp. 100-107, May 2017.

[28] Utility Connections in Port-Part 1: High Voltage Shore Connection (HVSC) Systems-General Requirements, IEC/ISO/IEEE Std. 80005-1, Jul. 2012.

[29] Utility Connections in Port-Part 2: High and Low Voltage Shore Connection Systems-Data Communication for Monitoring and Control, IEC/IEEE Std. 80005-2, Jun. 2016.

[30] N. Hatziargyriou, H. Asano, R. Iravani, and C. Marnay, "Microgrids-An overview of ongoing research, development, and demonstration projects," IEEE Power Energy Mag., vol. 5, no. 4, pp. 78-94, Jul./Aug. 2007.

[31] J. A. P. Lopes, C. L. Moreira, and A. G. Madureira, "Defining control strategies for microgrids islanded operation," IEEE Trans. Power Syst., vol. 21, no. 2, pp. 916-924, May 2006.

[32] N. B. Ahamad, M. Othman, J. C. Vasquez, J. M. Guerrero, and C. L. Su, "Optimal sizing and performance evaluation of a renewable energy based microgrid in future seaports," in Proc. IEEE Int. Conf. Ind. Technol., Lyon, France, Feb. 2018, pp. 1043-1048.

[33] G. Parise, L. Parise, L. Martirano, P. B. Chavdarian, C. L. Su, and A. Ferrante, "Wise port and business energy management-Port facilities, electrical power distribution," IEEE Trans. Ind. Appl., vol. 52, no. 1, pp. 18-24, Jan./Feb. 2016.

[34] H. Farhangi, "The path of the smart grid," IEEE Power Energy Mag., vol. 8, no. 1, pp. 18-28, Jan./Feb. 2010.

[35] C. H. Lo and N. Ansari, "The progressive smart grid system from both power and communications aspects," IEEE Commun. Surveys Tuts., vol. 14, no. 3, pp. 799-821, Jul./Sep. 2012.

[36] Icelandic New Energy-Icelandic Centre of Excellence for Sustainable Use and Conservation of the Ocean, "Electrification of harboursProject report," Nordic Marina, Reykjavík, Iceland, Tech. Rep., Dec. 2017. Accessed: Jan. 11, 2019. [Online]. Available: https://orkustofnun.is/ gogn/IslenskNyOrka/Electrification-of-harbours-2017.pdf

[37] A. Misra, G. Venkataramani, S. Gowrishankar, E. Ayyasam, and V. Ramalingam, "Renewable energy based smart microgrids - A pathway to green port development," Strategic Planning Energy Environ., vol. 37, no. 2, pp. 17-32, Sep. 2017.

38] Muni-Fed-Antea Group Energy Parners, LLC, "Microgrid technology white paper-Port of Long Beach," Muni-Fed-Antea Group Energy Parners, LLC, Long Beach, CA, USA, Tech. Rep., Aug. 2016. Accessed: Jan. 18, 2019. [Online]. Available: http://www.polb.com/civica/filebank/ blobdload.asp?BlobID $=13595$

[39] Air Resources Board (ARB)-California Environmental Protection Agency, "Evaluation of cold-ironing ocean-going vessels at California ports," ARB, California Environmental Protection Agency, Sacramento, CA, USA, Tech. Rep., Mar. 2006, Accessed: Jan. 18, 2019. [Online]. Available: https://www.arb.ca.gov/ports/marinevess/documents/coldironing 0306/execsum.pdf

[40] U.S. Environmental Protection Agency (EPA), "Shore power technology assessment at U.S. ports," U.S. EPA, Washington, DC, USA, Tech. Rep., Mar. 2017, Accessed: Jan. 18, 2019. [Online]. Available: https://www.epa. gov/sites/production/files/2017-05/documents/420r17004-2017-update .pdf

[41] K. L. Peterson, P. B. Chavdarian, M. Islam, and C. Cayanan, "Tackling ship pollution from the shore," IEEE Ind. Appl. Mag., vol. 15, no. 1, pp. 56-60, Jan./Feb. 2009.

[42] A. Wilske and C. Agren, "Shore connected electricity supply to vessels in the Port of Gothenburg," Pronet, Dec. 2008. Accessed: Jan. 18, 2019. [Online] Available: http://www.eltis.org/sites/default/files/casestudies/documents/15_5.pdf
[43] P. G. Rekdal, "Onshore power supply Oslo pilot-HVSC in port of Oslo," 628 in Proc. CleanShip Conf., Trelleborg, Sweden, Sep. 2013, pp. 1-35. 629

[44] S. Doves, "Alternative Maritime Power in the Port of Rotterdam - A 630 feasibility study into the use of shore-side electricity for containerships 631 moored at the Euromax terminal in Rotterdam," Port of Rotterdam 632 Authority, Rotterdam, The Netherlands, Tech. Rep., Sep. 2006, Accessed: 633 Jan. 18, 2019. [Online]. Available: http://www.ops.wpci.nl/_images/_ 634 downloads/_original/1266311641_reportshoreconnectedpowerporto - 635 frotterdam. pdf

[45] D. Jahn, "Environmental policy in the Port of Hamburg," Hamburg 637 Port Authority, Hamburg, Germany, Tech. Rep., Feb. 2017. Accessed: 638 Jan. 18, 2019. [Online]. Available: http://www2.convention.co.jp/ipc- 639 kobe/pdf/program/13th/sessionC/Hamburg.pdf

[46] C. Botana "Best practices in the sustainable development of the ports- 641 Port of Vigo: Green port," in Proc. Atlantic Stakeholders Platform Conf., 642 Porto, Portugal, Jan. 2015, pp. 1-14.

[47] O. Y. Yustiano, "Cost and benefit analysis of shore side electricity in 644 the port of Tanjung Perak, Indonesia," Master's thesis, World Maritime 645 University, Malmö, Sweden, 2014.

[48] Authority of the Port of Barcelona, "Map of Barcelona's port," Port 647 de Barcelona, 2018. Accessed: Jan. 21, 2019. [Online]. Available: 648 http://www.portdebarcelona.cat/en/web/el-port/mapa-guia 649

[49] Authority of the Port of Barcelona, "Port of Barcelona traffic statistics- 650 Accumulated data January 2019," Port of Barcelona, Statistics Service, 651 Tech. Rep., Feb. 2019. Accessed: March 4, 2019, [Online]. Available: 652 http://www.portdebarcelona.cat/en/web/autoritat-portuaria/estadisticas 653

[50] Marine Traffic, Arrivals and Departures at the port of Barcelona. 654 Accessed: Mar. 04, 2019. [Online]. Available: https://www.marinetraffic. 655 com/en/data/?asset_type $=$ arrivals_departures\&columns $=$ shipname, 656 move_type,port_type,port_name,ata_atd,origin_port_name,leg_start_ 657 port,intransit\&quicksearch|begins|BARCELONA|quicksearch_asset_id 658 $=$ Port-236

[51] Technical University of Denmark and World Bank Group, "Global 660 wind atlas." Accessed: Jan. 7, 2019. [Online]. Available: https:// 661 globalwindatlas.info/

[52] Joint Research Centre of the European Commission, "Photovoltaic ge- 663 ographical information system-Interactive maps," JRC Eur. Commis- 664 sion, Inst. Environ. Sustainability, Renewable Energies Unit, Ispra, Italy. 665 Accessed: Jan. 7, 2019. [Online]. Available: http://re.jrc.ec.europa.eu/ 666 pvgis/apps4/pvest.php

[53] S. Heier, Grid Integration of Wind Energy Conversion Systems. Chichester, 668 U.K.: Wiley, 1998, p. 34.

[54] E. Koutroulis and K. Kalaitzakis, "Design of a maximum power track- 670 ing system for wind-energy-conversion applications," IEEE Trans. Ind. 671 Electron., vol. 53, no. 2, pp. 486-494, Apr. 2006.

[55] T. K. Ghosh and M. A. Prelas, Energy Resources and Systems. Vol. 673 2: Renewable Resources. Dordrecht, The Netherlands: Springer, 2011, 674 pp. 21-23. 675

[56] Vestas, "The V150-4.2 MW IEC IIIB/IEC S," Vestas, Aarhus N, Den- 676 mark, Tech. Brochure. Accessed: Jan. 7, 2019. [Online]. Available: 677 https://www.vestas.com/en/products/4-mw-platform/v150-4_2_mw 678

[57] T. K. Ghosh and M. A. Prelas, Energy Resources and Systems. Vol. 679 2: Renewable Resources. Dordrecht, The Netherlands: Springer: 2011, 680 p. 80.

[58] Suntech, "Monocrystalline 144-cell module STP375S-24/Vfh," Tech. 682 Brochure. Accessed: Jan. 7, 2019. [Online]. Available: http://www. 683 suntech-power.com/productInfo.html?type $=1734$

[59] R. Vidal-Albalate, H. Beltran, A. Rolán, E. Belenguer, R. Peña, and 685 R. Blasco-Giménez, "Analysis of the performance of MMC under fault 686 conditions in HVDC-based offshore wind farms," IEEE Trans. Power Del., 687 vol. 31, no. 2, pp. 839-847, Apr. 2016.

[60] A. Cabrera-Tobar, E. Bullich-Massagué, M. Aragüés-Peñalba, and 689 O. Gomis-Bellmunt, "Topologies for large scale photovoltaic power 690 plants," Renewable Sustain. Energy Rev., vol. 59, pp. 309-319, Jun. 2016. 691

[61] S.-K. Chung, "A phase tracking system for three phase utility interface 692 inverters," IEEE Trans. Power. Electron., vol. 15, no. 3, pp. 431-438, 693 May 2000.

[62] P. Kundur, Power System Stability and Control. New York, NY, USA: 695 McGraw-Hill, 1994, pp. 581-626.

[63] L.-J. Cai and I. Erlich, "Simultaneous coordinated tuning of PSS and 697 FACTS damping controllers in large power systems," IEEE Trans. Power 698 Syst., vol. 20, no. 1, pp. 294-300, Feb. 2005. 